\title{
The Impact of the Covid 19 Pandemic on the Intrinsic and Extrinsic Motivation of The Panel Futsal Club During Covid-19 Pandemic
}

\author{
Rifqi Anas ${ }^{1,{ }^{*}}$ Dewa Kusuma ${ }^{2,}$ Fransisca Wijaya ${ }^{3,}$ David Prianto ${ }^{4}$ \\ 1,2,3,4 Department Sport Coaching Education, Universitas Negeri Surabaya \\ *Corresponding author. Email: rifqi.17060474025@mhs.unesa.ac.id
}

\begin{abstract}
Motivation has a vital role in sport. In March 2020, WHO (World Health Organization) declared that covid 19 was a pandemic because all citizens have the potential to catch the virus. The purpose of this study was to assess and know the level of intrinsic and extrinsic motivation of futsal athletes from the panel futsal club of Sumenep in the middle of the pandemic of covid 19. Descriptive quantitative was used as the method of this research. The target of this research was the futsal athletes from the panel futsal club of Sumenep. Purposive sampling was used as the sampling technique. There were 30 participants of this research with the age range between 15-23 years. Data collection techniques of this research used the questionnaire. Then, for data analysis techniques used descriptive analysis was used. The result of this research showed that in the middle of the pandemic of covid 19, the level of intrinsic and extrinsic motivation of the futsal athletes from the panel futsal club was 46,66\% which is categorized as medium. Therefore, it can be concluded that the covid 19 pandemics was bringing an impact to the athlete's level of motivation in practicing at the panel futsal club in Sumenep.
\end{abstract}

Keywords: Futsal, Covid-19, Motivation, Intrinsic, Extrinsic

\section{INTRODUCTION}

Futsal is an adjustment or modification of a soccer match played indoors; futsal is played by two groups, each group consisting of five individuals. But the rules are also different, as in kick-in into the field using feet in futsal. The goal is the same as soccer, which is to get the ball into the opponent's goal. The sport of futsal is currently experiencing a very extraordinary development which can be seen with the proliferation of futsal tournaments being held.

Exercise is an effort to develop the athlete's work capacity, skills, and psychological qualities with the aim of improving performance in achievement[2]. So that the training process becomes very important for every athlete in improving his ability, of course, with the goals set by the athlete. By setting goals, athletes will feel they have responsibility and enthusiasm to practice so that their goals are achieved. In the training process, of course, it is closely related to the motivation of the athlete. Because motivation plays an important role for athletes in training, with high motivation, high enthusiasm will be created in achieving goals which will undoubtedly have an impact on the training process.
On March 11, 2020, WHO (World Health Organization) decided that COVID-19 is a pandemic because it can attack and infect a person. Covid-19 cases in September 2021 in Indonesia with a total number of 4.15 million cases. Meanwhile, the number of victims who died due to COVID-19 was 138,000 people. This has increased the number of COVID-19 cases in Indonesia WHO emphasized that the COVID19 disease is a world crisis, which implies that every country must implement the principles by carrying out a welfare convention to limit the spread of covid 19, especially by wearing masks, recommendations for constantly washing hands and keeping a distance from everyone. In the world of sports, with the spread of Covid-19, it has become disrupted, such as the training process and the learning process. Where in the learning process and practice at home with face-to-face online, because of the hazardous covid-19 virus disease that threatens death, and the virus for which a cure has not been found. However, the Indonesian government vaccinates Indonesian citizens so that the body's immunity becomes more robust and immune to the virus. As a result of being this pandemic also impacts 
the implementation of sports competitions that have been postponed indefinitely.

Motivation is an exciting and essential field in human psychology. In sports, motivation plays a critical role in training. Because with motivation, athletes will be enthusiastic in practicing to achieve their goals. Some of the characteristics of motives include the source of the driving force and the impetus. Motivation has two types, namely intrinsic and extrinsic motivation. Intrinsic motivation is the determination or ambition that comes from the individual himself to carry out sports training activities. Extrinsic motivation is a determination that creates an urge to carry out actions outside the individual/person, for example, family, friends, and the environment, which are indicators of athletes in carrying out activities.

Researchers are interested in doing this research because of the problems that occurred during the COVID-19 pandemic, which impacted athletes' training motivation because the conditions before the pandemic were different from the pandemic conditions. Where before the pandemic, athletes had very high training motivation. It is indicated by the percentage of athletes' attendance at each exercise, which is always crowded. The situation became different when the COVID-19 pandemic which is currently a national disaster. The level of motivation of athletes has decreased, which is indicated by the intensity of attendance that is reduced compared to conditions before the pandemic. So that researchers can find out the impact of the COVID-19 pandemic on motivation to practice in futsal athletes because the role of reason is significant to the enthusiasm of athletes in carrying out or participating in training during the pandemic can see with the level of attendance of players.

The results of previous research by Pamungkas \& Mahfud showed that exercise motivation was in the excellent category based on intrinsic motivation, obtaining a score of 47.82\%[6]. And extrinsic motivation reached $46.66 \%$ in the excellent category. This shows that the pandemic affects the level of intrinsic and extrinsic motivation of athletes. The role of reason is an essential part of an athlete as a driving force in doing something so that good motivation will create a desire or enthusiasm in doing something. Compared to previous research, the advantage of this research is that this research was carried out in the new standard period, which means slowly several sports venues have been opened. With this change in conditions, the level of motivation to practice will undoubtedly be different compared to previous research conducted under conditions of lockdown or regional quarantine, so that many sports venues are closed in to reduce crowd levels to minimize the spread of the Covid-19 virus.

In this study, the author wanted to determine the motivation for practicing futsal club athletes during the Covid-19 pandemic, which became a national and even international disaster. The author wants to know the intrinsic and extrinsic motivation of the futsal club team athletes in Sumenep Regency.

\section{METHODS}

The method used in this research is quantitative descriptive research methods. Descriptive quantitative research in question is the strategy used in the examination to describe the information obtained in the investigation. Quantitative descriptive research is research to describe specific symptoms, phenomena, or events [3]. This research design uses survey research.

The sampling technique in this study is by using a purposive sampling technique. Purposive sampling is a method of determining non-probability samples with specific criteria for consideration [8]. The benchmark used in the study were athletes with an age range of 1523 years. The number of samples taken in this study was 30 athletes from the Panel Futsal Club in Sumenep Regency.

The technique of collecting data in this research is using a questionnaire/questionnaire. The questionnaire is a data collection conducted by researchers by giving a group of questions to respondents to answer. The questionnaire/questionnaire used has been validated by expert judgment, namely the Department of Sports Coaching Education lecturer, Universitas Negeri Surabaya, as a validator. The questionnaire contains several indicators of intrinsic motivation and extrinsic motivation. Intrinsic motivation indicators include interests, ideals, talents, physical rewards. Meanwhile, indicators of extrinsic motivation include rules, friends, parents, training programs, and facilities.

Data analysis techniques in this study used descriptive analysis. The results were obtained from the research sample using a questionnaire used as a diagram and then described in a percentage. The categorization of the mean and standard deviation according to Azwar uses the norm reference value (PAN) as follows[1] :

Table 1. Norm Reference Assessment

\begin{tabular}{|c|l|c|}
\hline No & \multicolumn{1}{|c|}{ Norm Range } & Category \\
\hline 1 & $\mathrm{X} \geq \mathrm{M}+1,5 \mathrm{SD}$ & Very High \\
\hline 2 & $\mathrm{X}+0,5 \mathrm{SD} \leq \mathrm{X}<\mathrm{M}+1,5$ & High \\
\hline 3 & $\mathrm{M}-0,5 \mathrm{SD} \leq \mathrm{X}<\mathrm{M}+0,5 \mathrm{SD}$ & Medium \\
\hline 4 & $\mathrm{M}-1,5 \mathrm{SD} \leq \mathrm{X}<\mathrm{M}-0,5 \mathrm{SD}$ & Low \\
\hline 5 & $\mathrm{X}<\mathrm{M}-1,5 \mathrm{SD}$ & Very Low \\
\hline
\end{tabular}

(Sumber : [1])

Table 1 above is a way of calculating data analysis to obtain the relative frequency of the percentage with the following formula:

$$
P=\frac{f}{n} \times 100 \%
$$

Keterangan :

p: percentage

$f:$ frequency

$n$ : number of cases (number of frequencies/number of individuals) 


\section{Flowchart of the research procedure}

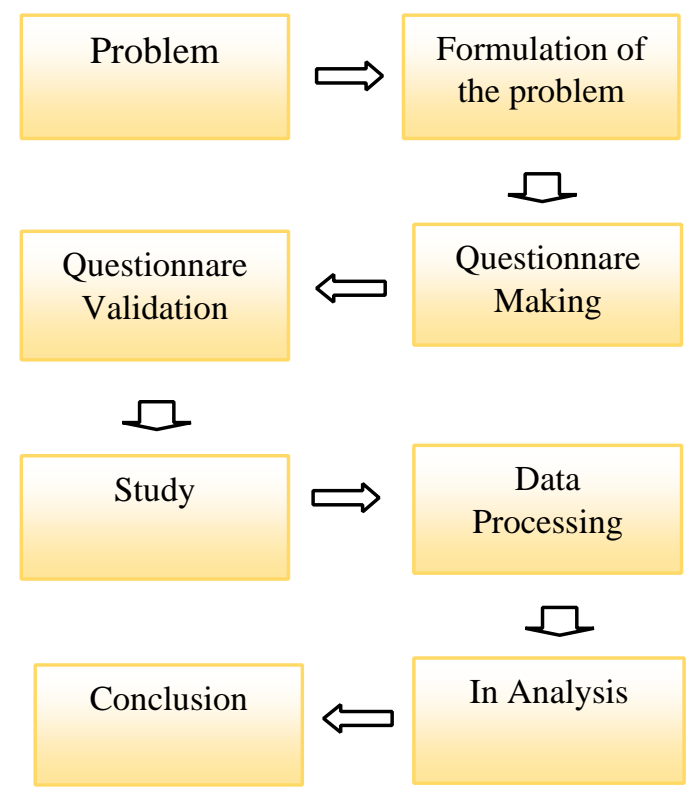

\section{RESULTS}

The results of this study aim to describe the data from a survey to determine how much the story of intrinsic and extrinsic motivation was obtained from the results of a questionnaire totaling 30 items. A statement was given to the sample. According to the results of the analysis, the following data were obtained.

Table 2. Descriptive statistics on athlete motivation

\begin{tabular}{|l|l|r|}
\hline $\mathrm{N}$ & Valid & 30 \\
\hline & Missing & 7 \\
\hline Mean & & 95.6333 \\
\hline Median & & 96.0000 \\
\hline Mode & & $91.00^{\mathrm{a}}$ \\
\hline Std.deviation & & 9.68640 \\
\hline Variance & & 93.826 \\
\hline Range & & 39.00 \\
\hline Minimum & & 73.00 \\
\hline Maximum & & 112.00 \\
\hline Sum & & 2869.00 \\
\hline
\end{tabular}

In table 2 above, the descriptive statistics on the motivation of athletes from the results of research conducted at the futsal club committee in Sumenep Regency, the average (mean) 95.6333, the median value (median) 96.0000, the most frequent value (mode) 91.00a. , Standard Deviation 9.68640, Variance 93,836, Range 39.00, the lowest value (minimum) 73.00, and the highest value (maximum) 112.00.

If it is explained in the form of a frequency distribution, the level of intrinsic and extrinsic motivation of the futsal club team in Kab. Sumenep, the results are described in table 3 as follows :
Table 3. Frequency distribution of the basis of the futsal team athletes in Kab. Suede

\begin{tabular}{|c|c|c|c|c|}
\hline No & Norm Range & $\begin{array}{c}\text { Categ } \\
\text { ory }\end{array}$ & Frequency & $\%$ \\
\hline 1 & $\mathrm{X} \geq \mathrm{M}+1,5 \mathrm{SD}$ & $\begin{array}{c}\text { Very } \\
\text { High }\end{array}$ & 3 & 10 \\
\hline 2 & $\begin{array}{c}\mathrm{M}+0,5 \mathrm{SD} \leq \\
\mathrm{X}<\mathrm{M}+1,5 \mathrm{SD}\end{array}$ & High & 5 & $\begin{array}{c}16,6 \\
6\end{array}$ \\
\hline 3 & $\begin{array}{c}\mathrm{M}-0,5 \mathrm{SD} \leq \mathrm{X}< \\
\mathrm{M}+0,5 \mathrm{SD}\end{array}$ & $\begin{array}{c}\text { Mediu } \\
\mathrm{m}\end{array}$ & 14 & $\begin{array}{c}46,6 \\
6\end{array}$ \\
\hline 4 & $\begin{array}{c}\mathrm{M}-1,5 \mathrm{SD} \leq \\
\mathrm{M}-0,5 \mathrm{SD}\end{array}$ & Low & 6 & 20 \\
\hline 5 & $\begin{array}{c}\mathrm{X}<\mathrm{M}-1,5 \\
\mathrm{SD}\end{array}$ & $\begin{array}{c}\text { Very } \\
\text { Low }\end{array}$ & 2 & 6,66 \\
\hline
\end{tabular}

The results of table 3 show the percentage of categorization of the impact of the COVID-19 pandemic on the intrinsic and extrinsic motivation of futsal team futsal athletes at the Kab. Sumenep namely $6.66 \%$ in the deficient category, $20 \%$ in the low class, $46.66 \%$ in the medium category, $16.66 \%$ in the high sort, and $10 \%$ in the very high category.

Diagram 1. Distribution of motivation frequency of Panel Futsal Club players in Sumenep Regency

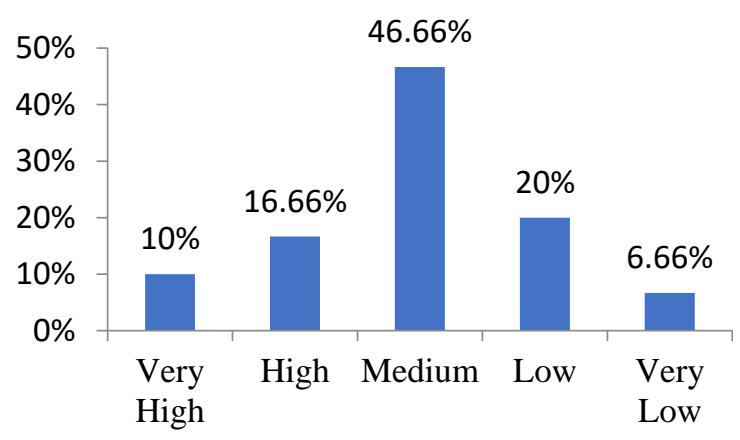

Table 4. Intrinsic Factor

\begin{tabular}{|c|c|c|}
\hline Sample Answer & Positive & Negative \\
\hline Strongly Agree & 159 & 19 \\
\hline Agree & 99 & 26 \\
\hline Disagree & 7 & 119 \\
\hline Strongly Disagree & 3 & 60 \\
\hline Total & 268 & 224 \\
\hline Average & 67 & 56 \\
\hline
\end{tabular}

Based on table 4 above, the respondents' answers are positive, with a total of 268 and an average of 67 . At the same time, the results of respondents' answers are negative, with 224 with an average of 56. 
Diagram 2. Intrinsic motivation percentage diagram

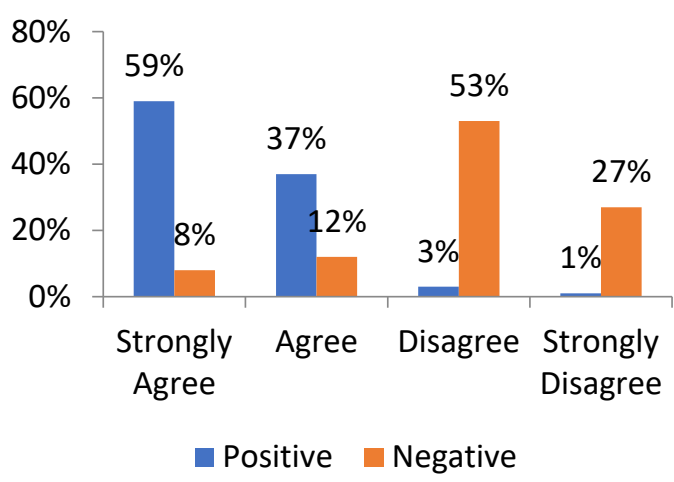

Referring to diagram 2 above, there are optimistic respondents' answers in the form of categories strongly agree by $59 \%$, agree $37 \%$, disagree $3 \%$, and strongly disagree by $1 \%$. However, the pessimistic respondents' answers in categories strongly agree $8 \%$, agree $12 \%$, disagree $53 \%$, and strongly disagree $27 \%$.

Diagram 3. Percentage diagram of intrinsic motivation (interest)

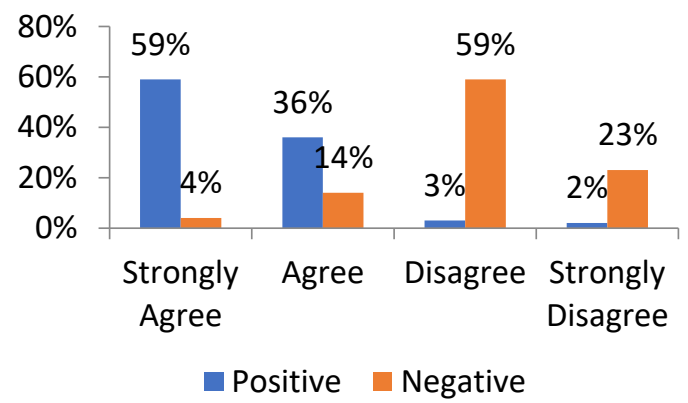

Based on the explanation of diagram 3 above, the answers of optimistic respondents in the category of strongly agree ranged at 59\%, agreed $36 \%$, disagreed $3 \%$, and strongly disagreed at $2 \%$. Meanwhile, the pessimistic respondents' answers in the category form strongly agree $4 \%$, agree $14 \%$, disagree $59 \%$, and strongly disagree $23 \%$.

Diagram 4. Intrinsic motivation percentage diagram (Talent)

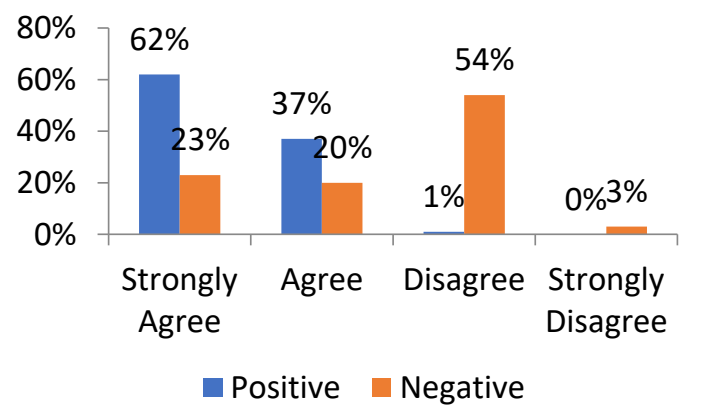

Referring to diagram 4 above, the positive sample answers in the category of strongly agree are around $62 \%$, agree $37 \%$, disagree $1 \%$, and strongly disagree at $0 \%$. While the results of the pessimistic respondents' answers in the category of strongly agree ranged from
$23 \%$, agreed $20 \%$, disagreed $54 \%$, and strongly disagreed $3 \%$.

Diagram 5. Intrinsic motivation percentage diagram (Ambition)

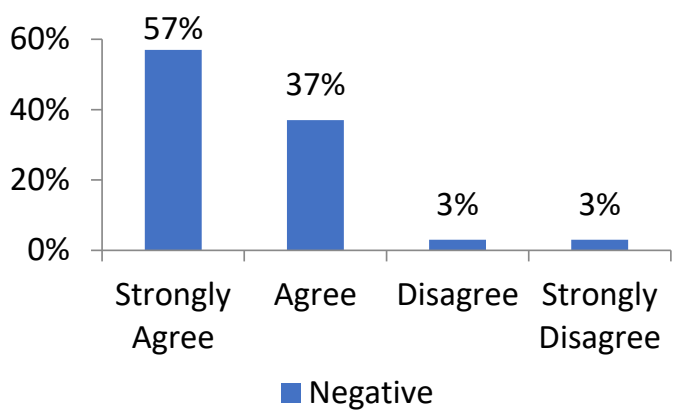

Figure 5, the optimistic respondents' answers into the category of strongly agree ranged from $57 \%$, agreed $37 \%$, disagreed $3 \%$, and strongly disagreed $3 \%$.

Diagram 6. Percentage diagram of intrinsic (physical) motivation

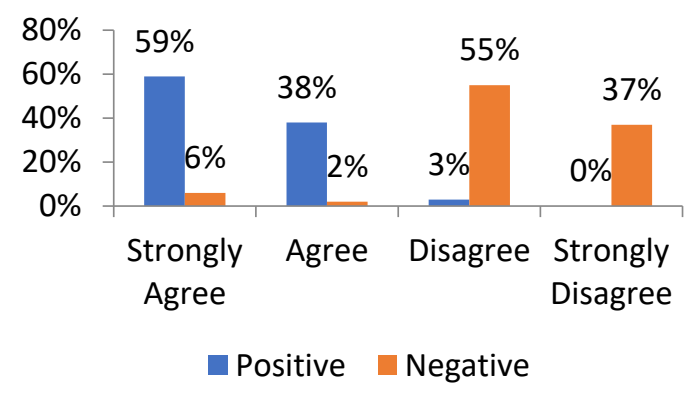

Based on diagram 6 above, the optimistic respondents' answers in the category of strongly agree at $59 \%$, agree $38 \%$, disagree $3 \%$, and strongly disagree at $0 \%$. While the results of the pessimistic respondents' answers in the category of strongly agree $6 \%$, agree $2 \%$, disagree $55 \%$, and strongly disagree at $37 \%$.

Diagram 7. Intrinsic motivation percentage diagram (Reward)

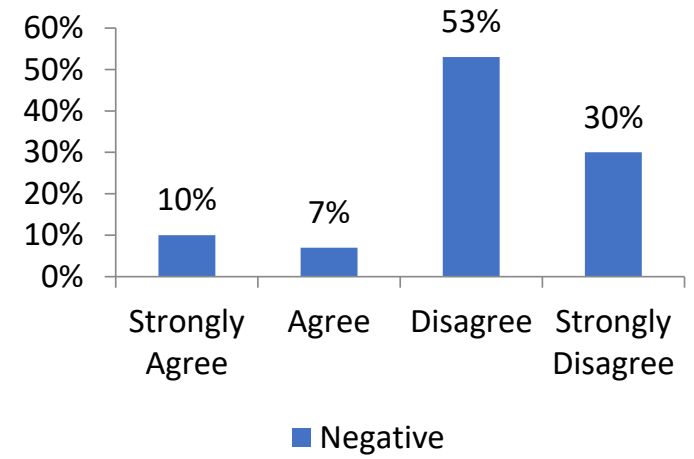

In diagram 7 above, the positive responses obtained by respondents strongly agree by $10 \%$, agree $7 \%$, disagree $53 \%$, and strongly disagree by $30 \%$. 


\section{Extrinsic Factor}

Diagram 8. Percentage diagram of extrinsic motivation

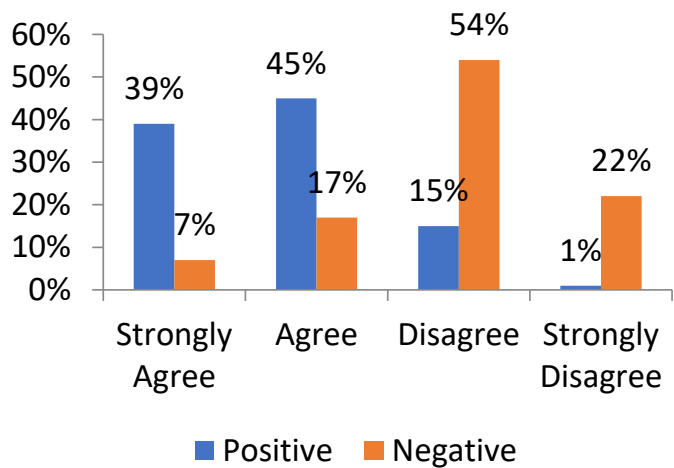

In diagram 8 above, the results obtained by optimistic respondents' answers in the category of strongly agree by $39 \%$, agree $45 \%$, disagree $15 \%$, and strongly disagree by $1 \%$. While the results of pessimistic respondents' answers in the category of strongly agree $7 \%$, agree $17 \%$, disagree $54 \%$, and strongly disagree at $22 \%$.

Diagram 9. Extrinsic motivation percentage diagram (Rules)

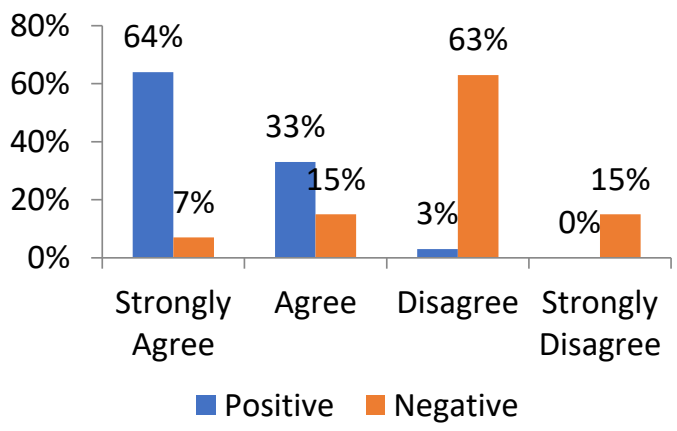

In diagram 9 above, the optimistic respondents' answers are strongly agreed at 64\%, agree 33\%, disagree $3 \%$, and strongly disagree at $0 \%$. While the results of pessimistic respondents' answers into the category of strongly agree $7 \%$, agree $15 \%$, disagree $63 \%$, and strongly disagree $15 \%$.

Diagram 10. Extrinsic motivation percentage diagram (Parents)

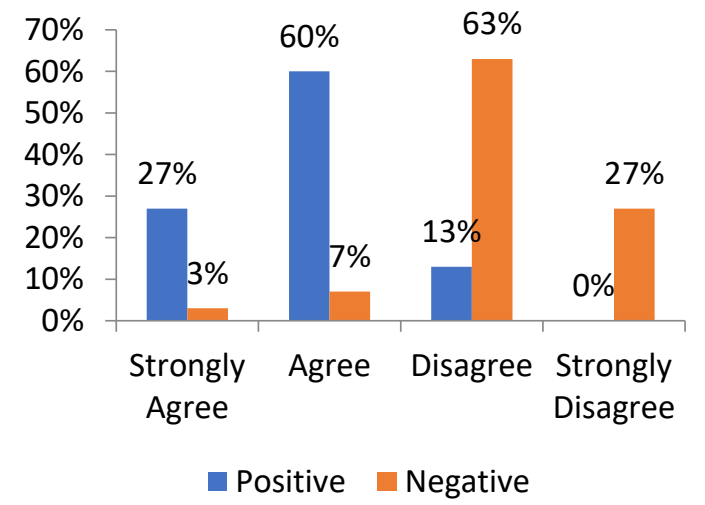

Based on diagram 10 above, the optimistic respondents' answers in the category of strongly agree at
$27 \%$, agree $60 \%$, disagree $13 \%$, and strongly disagree at $0 \%$. While the results of the pessimistic respondents' answers in the category of strongly agree $3 \%$, agree $7 \%$, disagree $63 \%$, and strongly disagree $27 \%$.

Diagram 11. Extrinsic motivation percentage diagram (Friends)

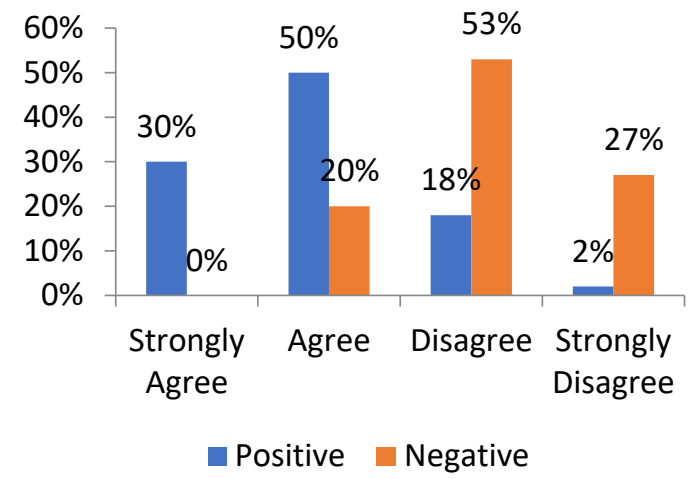

Referring to diagram 11 above, the optimistic respondents' answers into the category of strongly agree ranged from $30 \%$, agreed $50 \%$, disagreed $18 \%$, and strongly disagreed at $2 \%$. While the results of pessimistic respondents' answers in the category of strongly agree $0 \%$, agree $20 \%$, disagree $53 \%$, and strongly disagree $27 \%$.

Diagram 12. Extrinsic motivation percentage diagram (Exercise Program)

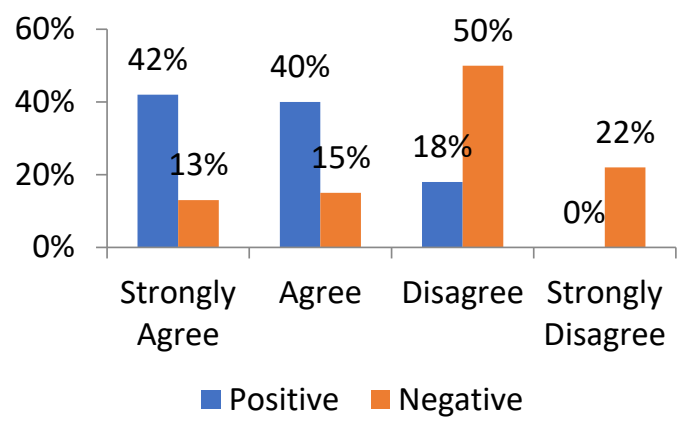

Based on diagram 12 above, the optimistic respondents' answers in the category of strongly agree at $42 \%$, agree $40 \%$, disagree $18 \%$, and strongly disagree at $0 \%$. While the results of pessimistic respondents' answers strongly agree $13 \%$, agree $15 \%$, disagree $63 \%$, and strongly disagree by $22 \%$.

Diagram 13. Extrinsic motivation percentage diagram (Facilities)

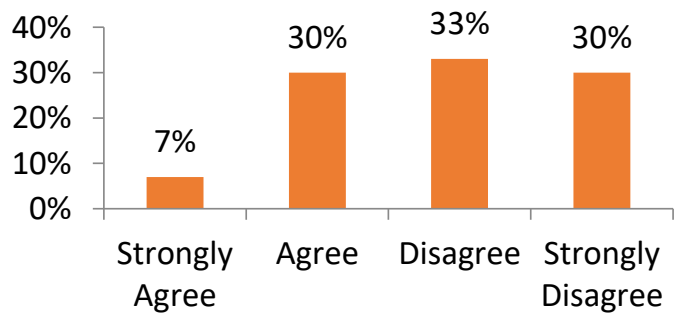

Negative 
Referring to diagram 13 above, the results of pessimistic respondents' answers in the category of strongly agree $7 \%$, agree $30 \%$, disagree $33 \%$, and strongly disagree $30 \%$.

\section{DISCUSSION}

Motivation is undoubtedly something positive that triggers someone to carry out activities to achieve something and determine the direction of achievement goals to be completed (goal setting). Motivation in the scope of sports is a mental aspect that can provide an essential role for sports coaches, both coaches, and teachers because motivation can make the basis for moving or guiding/directing a person's activities and behavior in sports [4]. Success in the coaching process depends not only on the stages of training but also on several factors from within the athlete and from outside the athlete that can affect the success or failure of coaching carried out [9].

There are five underlying indicators of intrinsic motivation: interests, talents, ideas, physical, and rewards. Intrinsic motivation is a form of embodiment of motivation that comes from individuals who are permanent, stable, and independent because they get encouragement from within [5]. Meanwhile, extrinsic motivation is known to come from outside a person's individual in carrying out a sports activity that tends to be unstable [5]. In extrinsic motivation, there are five indicators, including rules, parents, friends, training programs, and facilities.

After looking at the analysis results of the level of intrinsic and extrinsic motivation during the COVID-19 pandemic in the moderate category, it shows that the level of motivation to train athletes must be increased again because the training process becomes crucial in achieving a goal. The success of an exercise will create an achievement if it is done with an arduous effort and in earnest.

Previous research conducted by Rahman dan Kiram [7] before the pandemic showed that intrinsic and extrinsic motivation percentage was $57.67 \%$, which was in the high category. At the same time, the results of this study obtained the rate of intrinsic and extrinsic motivation that is equal to $46.66 \%$ who are in the middle/medium class. This proves that the COVID-19 pandemic influences or impacts the level of intrinsic and extrinsic motivation of athletes.

These results show that the COVID-19 pandemic has dramatically affected the level of motivation of the futsal club team athletes in the Sumenep Regency. Because before the pandemic, the level of motivation to train athletes was high, it can be seen by the level of attendance at training that was always present. In contrast to the conditions during the pandemic, the attendance rate decreased.

\section{CONCLUSION}

Based on the results of the research on the impact of the COVID-19 pandemic on the intrinsic and extrinsic motivation of the futsal club team athletes in Sumenep Regency, it shows that the level of motivation is in the moderate category, which is caused by the COVID-19 pandemic that hit so that it has an impact on the level of intrinsic and extrinsic motivation of athletes. Thus showing that the COVID-19 pandemic has an effect on the level of intrinsic and extrinsic motivation of the futsal club team athletes in Sumenep Regency. The impact that occurs due to the presence of covid-19, namely the level of attendance at training during the covid-19 pandemic. The limitations in the research experienced by the researcher are in the process of collecting data. The information provided by the respondents through questionnaires sometimes does not show the opinion of respondents who Actually, this happens because sometimes there are differences of opinion, assumptions, and different understanding of each respondent. Because this study was limited to the impact of the pandemic on intrinsic and extrinsic motivation. So the author suggests further research with a broader sample, more complex data analysis methods and techniques.

\section{AUTHOR CONTRIBUTIONS}

Conceptualization: Rifqi Anas, Fransisca Januarumi Marhaendra Wijaya; Formal Analysis: Rifqi Anas; Methodology: I Dewa Made Aryananda Wijaya Kusuma; Project administration: David Agus Prianto

\section{ACKNOWLEDGMENTS}

The author wishes to thank the staff of the Sports Sciences and all parties involved in this research.

\section{REFERENCES}

[1] Azwar, S. (2012). Penyusunan Skala Psikologi. Pustaka Belajar.

[2] Jufrianis. (2018). Pengaruh Model Latihan dan Motivasi Terhadap Peningkatan Kelincahan Atlet Club Futsal Nusantara Jakarta Timur. Jufrianis, 1(1), 65-72.

[3] Maksum, A. (2018). Metodologi Penelitian dalam Olahraga. Unesa University Press.

[4] Muskanan, K. (2015). Analisis Motivasi Berprestasi Atlet Pusat Pendidikan dan Latihan Olahraga Pelajar (PPLP) Provinsi Nusa Tenggara Timur. Jurnal Kebijakan \& Administrasi Publik, 19(2), 105-113.

[5] Mylsidayu, A. (2014). Psikologi Olahraga. PT. Bumi Aksara.

[6] Pamungkas, D., \& Mahfud, I. (2020). Tingkat Motivasi Latihan Ukm Taekwondo Satria Teknokrat Selama Pandemi Covid 2019. Journal of Physical Education (JouPE), 1(2), 6-9.

[7] Rahman, A., \& Kiram, Y. (2019). Motivasi Siswa Mengikuti Latihan Bolavolli di SMAN 1 Kota Solok Dalam Ekstrakulikuler. Jurnal Patriot, 1(1), 94-99.

[8] Sugiyono. (2012). Metode Penelitian Bisnis. Alfabeta.

[9] Utami, W. F. (2014). Analisis Pembinaan Atlet Kelas Remaja Cabang Olahraga Pencak Silat Di Kelas Olahraga Smp Negeri 1 Suboh Kabupaten Situbondo. Jurnal Unesa, 2(1), 58-61. 